Ozone Forming Potential at Rio de Janeiro Petrochemical Complex, Brazil

\author{
Siciliano, A. M.; Silva, C. E. F. C.; Corrêa, S. M.*
}

Rev. Virtual Quim., 2016, 8 (3), 1004-1019. Data de publicação na Web: 26 de abril de 2016

http://rvq.sbq.org.br

\begin{abstract}
Potencial de Formação de Ozônio no Complexo Petroquímico do Rio de Janeiro, Brasil
\end{abstract}

Resumo: Modelos de dispersão atmosférica tem sido amplamente empregados para estudar os padrões de dispersão atmosférica, predizer os efeitos das emissões, estimar riscos potenciais para a saúde humana, desenvolver políticas ambientais e avaliar o impacto na qualidade do ar. Modelos aprovados por agências regulatórias são frequentemente usados como ferramentas de simulação para análise de risco para a implantação e operação de empreendimentos. Este artigo trata das emissões de poluentes gasosos emitidos pelo Complexo Petroquímico do Rio de Janeiro (COMPERJ) e apresenta um estudo de caso da dispersão usando o modelo AERMOD e o modelo de trajetórias OZIPR acoplado ao modelo químico para avaliar a formação do ozônio troposférico. O COMPERJ está sendo instalado na região metropolitana do Rio de Janeiro e o inicio das operações previsto para 2016. Os resultados obtidos indicam que as concentrações de óxidos de nitrogênio (NOx) irão exceder os limites primários e secundários dos padrões brasileiros para qualidade do ar em algumas áreas. Como resultados dos altos níveis de NOx e a presença de compostos orgânicos voláteis (COV) são esperados altos níveis de ozônio na região estudada.

Palavras-chave: Atmosfera; dispersão; modelagem; ozônio; petroquímica; OZIPR; AERMOD.

\begin{abstract}
Air dispersion models have been widely used to investigate air dispersion patterns, to predict emissions behaviour, to estimate potential risks to human health, to develop environmental policies and to evaluate their impact on air quality. This paper considers gaseous pollutants emitted by a petrochemical complex and presents an air dispersion case study using the AERMOD model and the OZIPR trajectory model along with the SAPRC chemical mechanism to evaluate tropospheric ozone formation. The petrochemical complex considered is being installed in the Rio de Janeiro Metropolitan Area and is planned to start operations in 2016. The present work indicates that nitrogen oxides (NOx) concentrations will likely exceed the primary and secondary Brazilian national standards in some areas. As a result high levels of NOx in the presence of high VOC emissions would contribute to high levels of ozone.
\end{abstract}

Keywords: Atmosphere; dispersion; modeling; ozone; petrochemical, OZIPR, AERMOD.

\footnotetext{
* Rio de Janeiro State University, Rod. Presidente Dutra km 298, CEP 27537-000, Resende-RJ, Brazil.

Msergiomc@ueri.br

DOI: $10.5935 / 1984-6835.20160071$
} 


\title{
Ozone Forming Potential at Rio de Janeiro Petrochemical Complex, Brazil
}

\author{
Antonio Marco Siciliano, ${ }^{a}$ Carlos Eduardo F. C. e Silva, ${ }^{b}$ Sergio M. Corrêa ${ }^{a}$ \\ a Rio de Janeiro State University, Rod. Presidente Dutra km 298, CEP 27537-000, Resende-RJ, \\ Brazil. \\ ${ }^{b}$ Engeneering Simulation and Scientific Software, Av. Pres. Vargas 3131/1023, CEP 20210-031, \\ Rio de Janeiro-RJ, Brazil. \\ * sergiomc@uerj.br
}

Recebido em 21 de abril de 2016. Aceito para publicação em 21 de abril de 2016

\section{Introduction}

\section{Methodology}

2.1. Site Description

2.2. AERMOD Model

2.3. OZIPR and SAPRC Models

\section{Results and Discussion}

\section{Conclusions}

\section{Introduction}

Numerical modelling is often used to predict the impacts of future plants on air quality of the surrounding region. The predictions are based on atmospheric dispersion models approved by authorities, both in Brazil or elsewhere. When it is appropriate to use these models, one must simulate the worst-case scenarios for regulatory purposes (e.g., permission for installation and operation of industrial facilities). However, when an industrial facility is already in operation, other methods can be used to obtain greater accuracy, such as the online monitoring of pollutants through analysers and samplers.
In this work, an atmospheric Gaussian dispersion model was used to quantify the impacts on air quality of a petrochemical complex in Rio de Janeiro - Brazil, which that is still under construction and that will process 450,000 barrels of crude oil a day.

According to the Environmental Agency of Rio de Janeiro State (INEA), the preparation of an Environmental Impact Study (EIA) should include the development of an environmental impact assessment, specifically in relation to air quality. This assessment should be developed using mathematical models, and should characterise the pollutants regulated in Brazil, as detailed by the Brazilian National Environmental Council (CONAMA). ${ }^{1}$

According to Lora, ${ }^{2}$ the main gaseous 
emissions from the petroleum industry are Sulfur Dioxide $\left(\mathrm{SO}_{2}\right)$, Hydrogen Sulfide $\left(\mathrm{H}_{2} \mathrm{~S}\right)$, Ammonia $\left(\mathrm{NH}_{3}\right)$, Nitrogen Oxides (NOx), Carbon Monoxide (CO), hydrocarbons, mercaptans, acids, aldehydes, and ketones. Boilers and industrial furnaces, present in any chemical process, are responsible for emissions of $\mathrm{NOx}, \mathrm{SO}_{2}, \mathrm{CO}$, aldehydes, organic acids and Polycyclic Aromatic Hydrocarbons (PAH). The main sources of these pollutants are the numerous operations of heating and steam generation, which are processes that involve combustion reactions.

Oil refining is composed of physical, thermal and chemical separation of crude oil into its main fractions, which are then processed through a series of separation steps and conversions. The primary products of this industry are classified into the following categories: ${ }^{3}$

- Fuel (petrol, diesel, fuel oil, liquefied petroleum gas (LPG), aviation gasoline, residual fuel oil, kerosene and coke);

- Non-fuel end products (solvents, lubricating oils, greases, waxes, asphalt and coke); and

- Petrochemical feedstocks (naphtha, ethane, propane, butane, ethylene, propylene, butadiene, benzene, toluene and xylene) used in the production of fertilizers, pesticides, paint, grease, solvents, cleaning materials, detergents, refrigerants, antifreezing, resins, sealants, coatings, rubbers, plastics and synthetic fibres.

According to Chereseminof, ${ }^{3}$ about $90 \%$ of petroleum products used in the USA are of the fuel category, and $43 \%$ of that is gasoline. In Brazil in 2007, approximately $95 \%$ of petroleum products used were in the fuel category, and $18 \%$ of that was gasoline, as reported by the National Energy Balance. ${ }^{4}$

Crude oil is a mixture of different hydrocarbons with small amounts of impurities. The composition of crude oil can vary significantly depending on the source. Therefore oil refineries are complex systems of multiple operations that vary based on the properties of the crude oil and the desired end products. Thus, no two refineries are the same.

In the present work the dispersion of primary pollutants from stationary sources of the petrochemical complex will be modelled using the Gaussian plume dispersion model AERMOD (AERMIC Model - American Meteorological Society and United States Environmental Protection Agency) and the pollutants concentration obtained for ambient air will be used to model the ozone forming potential using the trajectories model OZIPR (Ozone Isoploth Package for Research) along with the chemical mechanism SAPRC (State-wide Air Pollution Research Centre).

One can understand the model as an air column that covers the studied area and is projected upward into the atmosphere, like a box with a movable cover, and is a function of the height of the mixed layer throughout the day. The entire box is considered perfectly homogeneous and moves according to the trajectory of the wind, but does not expand horizontally. Emissions from the base of the column are computed, and wet and dry depositions are considered.

The model SAPRC was developed by Carter ${ }^{5}$ and has since undergone numerous changes and updates. Due to its structure and extensive documentation, its use and modifications are greatly enhanced.

The SAPRC is a model that includes thermal and photochemical reactions comprising about 140 reactions and 80 species. However, not all VOC species are treated explicitly within its mechanism.

Due to the inability to represent the chemical model with its entire explicit species, the rate constants have been grouped into ten classes. However, some species, with well-established rate constants and stoichiometry and that were of great importance for atmospheric chemistry, were kept isolated in an explicit form. These grouping criteria consider structure similarity and reactivity. ${ }^{5}$ Five groups of alkanes, two groups of alkenes and two groups of 
aromatics are used. The description of each group can be found in our previous works ${ }^{6-10}$ as well as in the reactions upgraded in the SAPRC 2005 version, for the reactions involving aldehydes, alcohols and some mono substituted aromatics. ${ }^{6-8}$

It is known that different types of VOC have different reaction rates for ozone formation and other secondary pollutants in mixtures of $\mathrm{VOC} / \mathrm{NOx}$ in the presence of sunlight. In general, regardless of the chosen reactivity scale, the reactivity of VOC tends to follow the following order: ${ }^{11}$ alkenes with internal double bonds, di- and trimethyl aromatics, terminal alkenes, ethylene, methyl aromatics, alkanes with five carbons and alkanes between 2 to 5 carbons. It is worth noting that the effect of a given $V O C$ on ozone formation will depend not only on the VOC reaction rate and their reaction mechanism, but also on the nature of the air where the VOC is emitted, including the effect of other pollutants and their concentrations.

To perform the simulations for the ozone forming potential, the following data was used:

- Initial concentration of $\mathrm{CO}, \mathrm{VOC}$ and NOx, in ppm;

- Hourly emissions of $\mathrm{CO}, \mathrm{VOC}$ and NOx, in $\mathrm{kg} \mathrm{h}^{-1} \mathrm{~km}^{-2}$;

- VOC speciation;

- Hourly meteorological data;

- Geographical coordinates of the area, and day, hour, month and year of study, used to calculate incoming solar radiation;

- Model representing chemical reactions in the studied atmosphere.

Dispersion models as AERMOD use mathematical equations describing the behaviour of the atmosphere, ${ }^{12}$ including scattering phenomena, to describe physical and chemical processes within the plume and to calculate concentrations of desired species at various locations. AERMOD is an air dispersion model based on planetary boundary layer theory and incorporate building downwash algorithms, advanced depositional parameters, local terrain effects, and advanced meteorological turbulence calculations.

Souto González et al. ${ }^{13}$ pointed out that air dispersion modelling is a powerful tool not only for research, but also for education in environmental engineering. These air dispersion models have been widely used to investigate the patterns of dispersal behaviour for air emissions in some areas ${ }^{14}$ and to estimate potential risks to human health. ${ }^{15}$

AERMOD was specifically developed to support the modelling programs of the Environmental Protection Agency of the United States (U.S.EPA) for the purpose of regulation and for gathering the latest advances in atmospheric dispersion modelling. Thus, it can be considered as the state-of-the-art in the simulation of atmospheric pollutant dispersion at local scale and can be used to determine pollutant concentrations and deposition fluxes from a variety of sources associated with an industrial complex, for example. Details can be found in our previous publication. ${ }^{16}$

\section{Methodology}

\subsection{Site Description}

The petrochemical complex is located in the Rio de Janeiro Metropolitan Area (RJMA) in the city of Itaboraí, eastern state of Rio de Janeiro, with twelve millions inhabitants distributed in $6,500 \mathrm{~km}^{2}$. The area has very little vegetation and is sparsely populated. The complex is located near Guanabara Bay and some heavily populated cities are located within a radius of $20 \mathrm{~km}$ from the centre of the petrochemical complex, with an estimated population over 380,000 distributed over 11 cities. The geographical 
area is presented in Figure 1.

COMPERJ strategic objective is to expand Petrobras' refining capacity to meet the growth in demand for oil products in Brazil, such as diesel fuel, petrochemical naphtha, jet fuel, coke and LPG (cooking gas). The first refinery is expected to go on stream in August 2016, with a refining capacity of 165,000 barrels of oil per day and will be expanded up to 450,000 barrels per day.

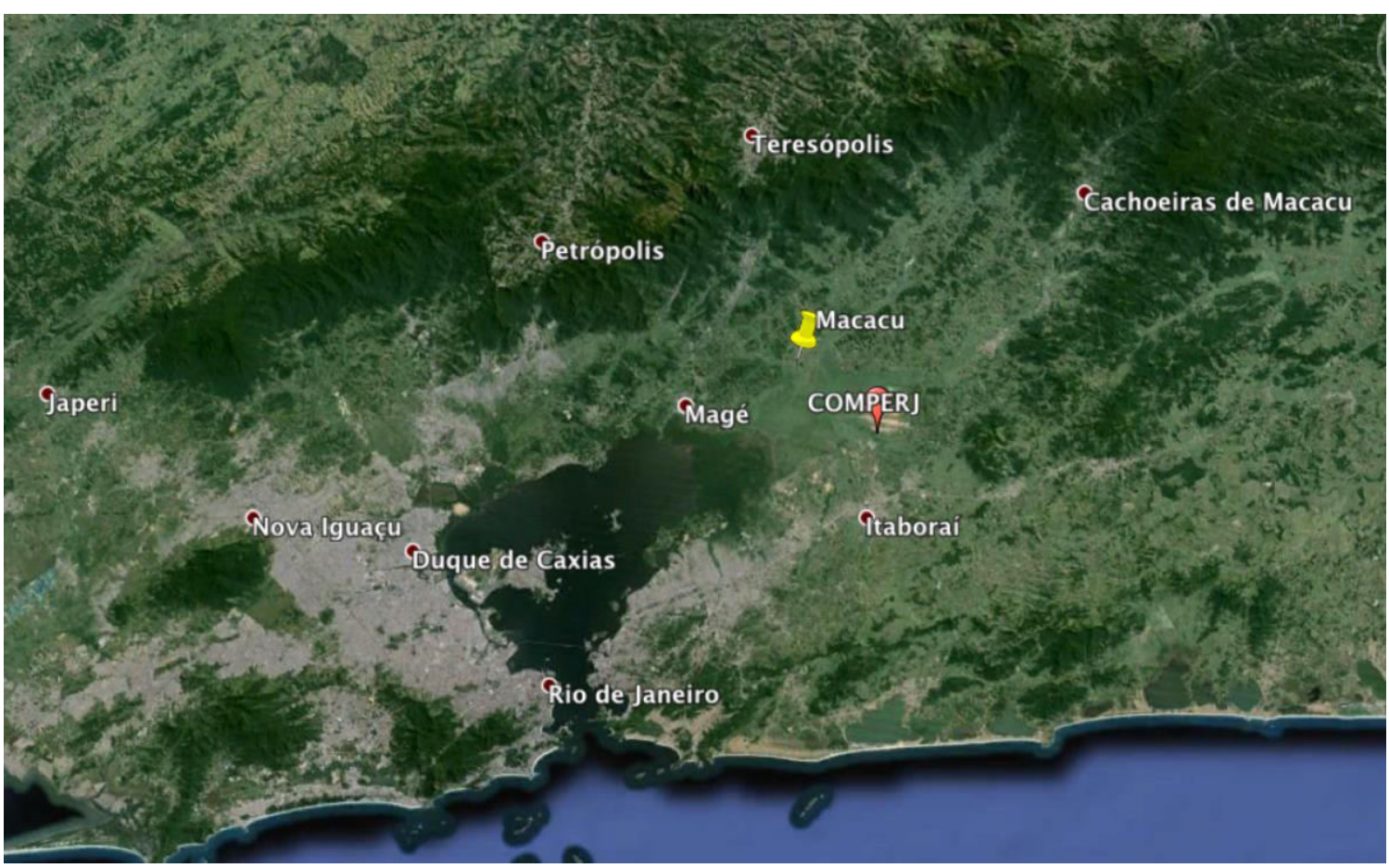

Figure 1. Location of the studied area of COMPERJ and meteorological station (Macacu) (Google Earth)

\subsection{AERMOD model}

For dispersion plumes calculations, meteorological, topographic and emissions data was used. Meteorological data from the meteorological station located at Macacu ($22.616029 \mathrm{~S},-42.931789 \mathrm{~W})$, reported in the Environmental Impact Study ${ }^{17}$ was used for this petrochemical complex. Terrain data including terrain height was obtained by using the Google Earth tool. A grid with twenty points in geodetic Cartesian UTM units on the $X$ and $Y$ axes with a spacing of $600 \mathrm{~m}$ was set up to generate a mesh over an area of $144 \mathrm{~km}^{2}$ comprising the complex. The influence of topography is minimal because the terrain is flat, with an average elevation of $14 \mathrm{~m}$ with a maximum value of $105 \mathrm{~m}$.

Emission data was taken from 42 chimneys $^{17}$ using internal fuel oil without nitrogen and sulphur (nitrogen content of $0.9 \% \mathrm{w} / \mathrm{w}$ and sulphur content of $1.0 \% \mathrm{w} / \mathrm{w}$ ) produced by the petrochemical complex itself for their furnaces and also as an external fuel oil for boilers.

The plume dispersion of $\mathrm{SO}_{2}, \mathrm{NOx}, \mathrm{PM}_{10}$ (particulate matter greater than $10 \mu \mathrm{m}$ ) and $\mathrm{CO}$ was simulated for different periods. The option of rural terrain feature was chosen, which provided a reference for vertical ascent of the plume, different from urban terrain, depending on the soil cover type and, consequently, its absorption and re-emission of solar radiation. Downwash effects were not considered due to lack of buildings set in the current stage of development that could promote changes of the plume motion.

The modelling of plumes was performed 
for several periods of time over six months using the meteorological data that was available. The value for the $1 \mathrm{~h}$ scenario shows the worst case scenario in the 6month study (low dispersion condition). In the same way, the results presented for the 8 $\mathrm{h}$ scenario was the $8 \mathrm{~h}$ period of consecutive meteorological data set over the past six months that had the worst dispersion condition. Details about the scenarios provided by AERMOD outputs are provided in an U.S. EPA report. ${ }^{18}$

\subsection{OZIPR and SAPRC models}

To perform the simulations of tropospheric ozone formation from the emissions of primary pollutants, the trajectory model OZIPR coupled with the chemical model SAPRC was used. Both are public domain, have wide acceptance in academia and international agencies, and are relatively simple to work with. Moreover, its chemical mechanism is very detailed for photochemical reactions in the troposphere. The trajectory model OZIPR $^{19,20}$ was developed by the U.S.EPA as a support for the scenario forecasting of urban air pollution episodes.

Details of the models can be obtained in our previous publications. ${ }^{6,8,9,21}$ For the VOC, speciation data ${ }^{9}$ obtained for the Rio de Janeiro Metropolitan Area (RJMA) was used with sampling and chromatographic analysis performed in a nearby refinery $(40 \mathrm{~km}$ to the
East), which was extrapolated as the study area and whose petrochemical complex is still under construction. The speciation at both sites followed the methodologies detailed at Compendium of Methods for the Determination of Toxic Organic Compounds in Ambient Air TO-14 and TO-15 from U.S.EPA, ${ }^{22.23}$ which basically consists of air sampling using stainless steel electropolished canisters and analysis by gas chromatography with detection by mass spectrometry and flame ionization (GC-MS and GC-FID).

Carbonyl compounds were routinely sampled and analysed following the TO-11A methodology from U.S.EPA ${ }^{24}$ and details are given in previous works. ${ }^{25-27}$ For the speciation presented in Table 1 , the evaluation of the incremental reactivity (IR) scale for VOC for the worst ozone scenario was done according to the proposed method provided in the documentation for the latest version of the trajectory model OZIPR ${ }^{20}$ and detailed in Orlando et al. ${ }^{6}$

It was performed by the addition/reduction of $0.2 \%$ of the total VOC for each VOC. Each VOC had its concentration increased, while the remaining VOC were kept unchanged. After this procedure, the fractions of the groups were recalculated and implemented into the model. Subsequently, the positive incremental reactivity (IR+) was determined as Eq. 1.

Then, the concentration of each VOC was decreased. The change in ozone indicates the negative incremental reactivity (IR-), as described in Eq. 2.

$$
\begin{gathered}
\mathrm{IR}+=\frac{\left[\mathrm{O}_{3}\right]^{\mathrm{inc}}-\left[\mathrm{O}_{3}\right]^{\text {base }}}{+0.002 \times[\mathrm{VOCs}]^{\text {base }}} \\
\mathrm{IR}-=\frac{\left[\mathrm{O}_{3}\right]^{\mathrm{inc}}-\left[\mathrm{O}_{3}\right]^{\text {base }}}{-0.002 \times[\mathrm{VOCs}]^{\text {base }}}
\end{gathered}
$$


Table 1. VOCs speciation for RJMA (2012) and for a nearby refinery (REF) used in the simulations

\begin{tabular}{|c|c|c|c|c|c|c|}
\hline \multirow[t]{2}{*}{ Group description } & \multicolumn{2}{|c|}{ Total ppmC } & \multicolumn{2}{|c|}{ Fraction } & \multicolumn{2}{|c|}{ Average C } \\
\hline & RJMA & REF & RJMA & REF & RJMA & REF \\
\hline Alkanes $\mathrm{k}_{\mathrm{OH}}<5 \times 10^{2} \mathrm{ppm}^{-1} \mathrm{~min}^{-1}$ & 0.016 & 1.070 & 0.0105 & 0.0042 & 2.000 & 1.070 \\
\hline 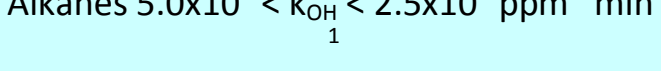 & 0.001 & 3.209 & 0.0004 & 0.0014 & 3.000 & 3.209 \\
\hline Alkanes $2.5 \times 10^{3}<\mathrm{k}_{\mathrm{OH}}<5.0 \times 10^{3} \mathrm{ppm}^{-1} \mathrm{~min}^{-}$ & & & & & & \\
\hline & 0.048 & 4.439 & 0.0312 & 0.0062 & 4.127 & 4.439 \\
\hline Alkanes $5.0 \times 10^{3}<\mathrm{k}_{\mathrm{OH}}<1.0 \times 10^{4} \mathrm{ppm}^{-1} \mathrm{~min}^{-}$ & & & & & & \\
\hline 1 & 0.239 & 5.703 & 0.1541 & 0.0141 & 5.361 & 5.703 \\
\hline Alkanes $\mathrm{k}_{\mathrm{OH}}>1 \times 10^{4} \mathrm{ppm}^{-1} \mathrm{~min}^{-1}$ & 0.064 & 8.745 & 0.0410 & 0.0219 & 7.732 & 8.745 \\
\hline Alkenes $\mathrm{k}_{\mathrm{OH}}<7 \times 10^{4} \mathrm{ppm}^{-1} \mathrm{~min}^{-1}$ & 0.046 & 4.540 & 0.0296 & 0.0177 & 4.000 & 4.540 \\
\hline Alkenes $\mathrm{k}_{\mathrm{OH}}>7 \times 10^{4} \mathrm{ppm}^{-1} \mathrm{~min}^{-1}$ & 0.024 & 5.151 & 0.0154 & 0.0319 & 4.685 & 5.151 \\
\hline Aromatic $\mathrm{k}_{\mathrm{OH}}<2 \times 10^{4} \mathrm{ppm}^{-1} \mathrm{~min}^{-1}$ & 0.325 & 7.413 & 0.2098 & 0.0552 & 7.277 & 7.413 \\
\hline Aromatic $\mathrm{k}_{\mathrm{OH}}>2 \times 10^{4} \mathrm{ppm}^{-1} \mathrm{~min}^{-1}$ & 0.585 & 8.280 & 0.3773 & 0.0552 & 8.198 & 8.280 \\
\hline Aldehydes $>$ C3 & 0.014 & 5.621 & 0.0087 & 0.0123 & 4.000 & 5.621 \\
\hline Aromatic aldehydes & 0.000 & 7.000 & 0.0000 & 0.0021 & 7.000 & 7.000 \\
\hline Ketones $\mathrm{k}_{\mathrm{OH}}<5 \times 10^{-12} \mathrm{~cm}^{3}$ molec $^{-2} \mathrm{~s}^{-1}$ & 0.000 & 4.000 & 0.0000 & 0.0032 & 4.000 & 4.000 \\
\hline Ketones $\mathrm{k}_{\mathrm{OH}}>5 \times 10^{-12} \mathrm{~cm}^{3} \mathrm{molec}^{-2} \mathrm{~s}^{-1}$ & 0.009 & 3.691 & 0.0057 & 0.0039 & 3.000 & 3.691 \\
\hline Terpenes & 0.005 & 10.000 & 0.0031 & 0.0000 & 10.000 & 10.000 \\
\hline Methane & 0.000 & 1.000 & 0.0000 & 0.7488 & 1.000 & 1.000 \\
\hline Carbon monoxide & 0.000 & 1.000 & 0.0000 & 0.0000 & 1.000 & 1.000 \\
\hline Formaldehyde & 0.051 & 1.000 & 0.0328 & 0.0067 & 1.000 & 1.000 \\
\hline Acetaldehyde & 0.020 & 2.000 & 0.0126 & 0.0063 & 2.000 & 2.000 \\
\hline PAN & 0.000 & 2.000 & 0.0000 & 0.0000 & 2.000 & 2.000 \\
\hline Ethane & 0.018 & 2.000 & 0.0118 & 0.0000 & 2.000 & 2.000 \\
\hline Ethanol & 0.036 & 2.000 & 0.0235 & 0.0026 & 2.000 & 2.000 \\
\hline Glyoxal & 0.000 & 2.000 & 0.0000 & 0.0000 & 2.000 & 2.000 \\
\hline Acetone & 0.051 & 3.000 & 0.0327 & 0.0051 & 3.000 & 3.000 \\
\hline Acroleine & 0.000 & 3.000 & 0.0000 & 0.0011 & 3.000 & 3.000 \\
\hline Methyl-glyoxal & 0.000 & 3.000 & 0.0000 & 0.0000 & 3.000 & 3.000 \\
\hline Biacetil & 0.000 & 4.000 & 0.0000 & 0.0000 & 4.000 & 4.000 \\
\hline Methacroleine & 0.000 & 4.000 & 0.0000 & 0.0000 & 4.000 & 4.000 \\
\hline Methyl-vinyl-ketone & 0.000 & 4.000 & 0.0000 & 0.0000 & 4.000 & 4.000 \\
\hline Isoprene & 0.000 & 5.000 & 0.0000 & 0.0000 & 5.000 & 5.000 \\
\hline Phenols & 0.000 & 6.000 & 0.0000 & 0.0000 & 6.000 & 6.000 \\
\hline Cresols & 0.000 & 7.000 & 0.0000 & 0.0000 & 7.000 & 7.000 \\
\hline
\end{tabular}

Although the equations presented for IR+ and IR- are similar, the results for each IR are different, because atmospheric chemistry is highly non-linear. The addition/removal of an individual VOC can lead to different values for ozone and other secondary pollutants.

Finally, the average between the values of $\mathrm{IR}+$ and IR- provided values of incremental reactivity (IR) for each VOC found.
The meteorological data used was from Corrêa et al. ${ }^{9}$ for the RJMA (Table 2), and the values for initial pollutant concentrations were $0.18 \mathrm{ppm}$ for NOx, $1.77 \mathrm{ppm}$ for $\mathrm{CO}$ and $1.44 \mathrm{ppm}$ for $\mathrm{VOC}$, which were average values measured between 6 to 9 AM local time by automated analysers from Thermo Scientific (model 42i for NOx, model 48i for $\mathrm{CO}$ and model $49 \mathrm{i}$ for $\mathrm{O}_{3}$ ). Deposition rates are presented in Table 3. 
Table 2. Meteorological data for the studied area (average values) used in the simulations

\begin{tabular}{cccc}
\hline Hour & Temp. -C & RH (\%) & Mixing Height (m) \\
\hline 6:00 & 26.6 & 77.5 & 600 \\
7:00 & 27.8 & 72.6 & 700 \\
8:00 & 29.0 & 66.9 & 700 \\
9:00 & 29.9 & 61.9 & 880 \\
10:00 & 30.7 & 58.4 & 1243 \\
11:00 & 31.4 & 55.4 & 1600 \\
12:00 & 31.8 & 54.0 & 1710 \\
13:00 & 31.9 & 53.4 & 1816 \\
14:00 & 31.7 & 54.5 & 1902 \\
15:00 & 31.1 & 55.9 & 1666 \\
16:00 & 30.2 & 59.4 & 890 \\
17:00 & 29.0 & 63.8 & 790 \\
18:00 & 28.1 & 69.9 & 715 \\
\hline
\end{tabular}

Table 3. Deposition rates for the main species

\begin{tabular}{ccc}
\hline Species & Min. Value $\left(\mathrm{cm} \mathrm{s}^{-1}\right)$ & Max. Value $\left(\mathrm{cm} \mathrm{s}^{-1}\right)$ \\
\hline $\mathrm{NO}_{2}$ & 0.1 & 0.2 \\
$\mathrm{O}_{3}$ & 1.0 & 1.0 \\
$\mathrm{HNO}_{3}$ & 1.3 & 1.5 \\
$\mathrm{H}_{2} \mathrm{O}_{2}$ & 1.7 & 2.0 \\
$\mathrm{PAN}$ & 0.4 & 0.6 \\
$\mathrm{CO}$ & 1.0 & 1.5 \\
\hline
\end{tabular}

The emission data used for NOx and CO was taken from EIA, ${ }^{17}$ which corresponds to respectively 480 and $103 \mathrm{~g} \mathrm{~s}^{-1}$. When referenced to the RJMA area, they can be extrapolated to 1.44 and $0.311 \mathrm{~kg} \mathrm{~h}^{-1} \mathrm{~km}^{-2}$ for NOx and $\mathrm{CO}$, respectively.

For the case of hydrocarbon emissions in a refinery, an emission factor of $1.0 \mathrm{~kg}$ VOC per $t$ of crude oil processed was used. The calculation presented below shows how emission values for this petrochemical complex of $8,182 \mathrm{t}$ of VOC per year was found.

The value of $8,182 \mathrm{t}$ of $\mathrm{VOC}$ per year corresponds to $0.78 \mathrm{~kg} \mathrm{~h}^{-1} \mathrm{~km}^{-2}$ when referenced to the RJMA. Besides the contribution of the petrochemical complex, the data surveyed by INEA was used to simulate ozone. ${ }^{28}$ This data does not include total mobile or total emissions for the study area, so we decided to adopt the studied case as the RJMA as a whole. INEA annual report $^{28}$ showed an emission of $8.61 \mathrm{~kg} \mathrm{~h}^{-1}$ $\mathrm{km}^{-2}$ for NOx, $30.54 \mathrm{~kg} \mathrm{~h}^{-1} \mathrm{~km}^{-2}$ for CO and 
$7.54 \mathrm{~kg} \mathrm{~h}^{-1} \mathrm{~km}^{-2}$ for VOC.

After finding the results for ozone, a sensitivity analysis was used by decreasing the emission of NOx and VOC by 5, 10, 20 and $30 \%$ with the use of the ozone isopleths to support the analysis.

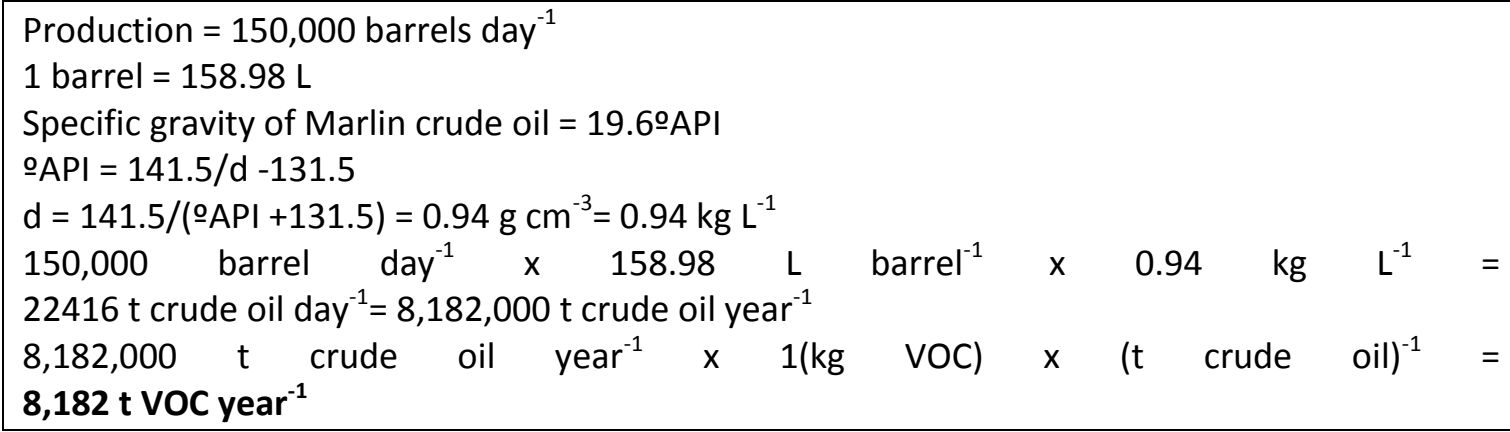

\section{Results and Discussion}

The results obtained through plume dispersion modelling are presented as illustrations for $\mathrm{NOx}$ and $\mathrm{SO}_{2}$, but results for Particulate Matter (PM10) and CO will also be discussed. The report specifically handles the emission rates, meteorology and topography described above, and the results are interpreted in the context of current legislation. It is noteworthy that the values to be displayed for the pollutants listed only considered the contribution of stack emissions from the petrochemical complex in the region of study. These emissions will increase with pollutants from the

(a)

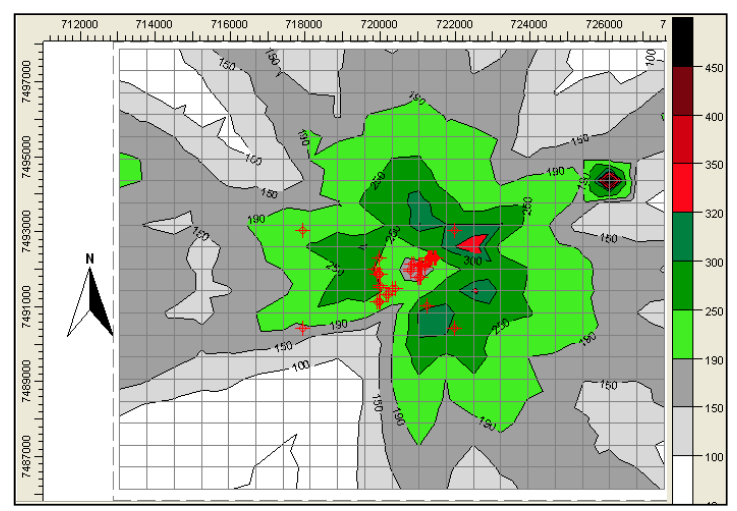

neighbourhood, local emissions (anthropogenic and natural), and future projects that will be considered around the complex. The results of the simulation for ozone using OZIPR and SAPRC are also presented. In the case of this simulation, scenarios considering all emissions currently present in the region were addressed in a generic way.

Figures $2 a$ and $2 b$ are presented for NOx and $\mathrm{SO}_{2}$ plumes for the $1 \mathrm{~h}$ scenario as an illustration. Figure $2 \mathrm{a}$ presents the average concentration in $\mu \mathrm{g} \mathrm{m} \mathrm{m}^{-3}$ within the $1 \mathrm{~h}$ scenario to allow comparisons with legislated limits. The results for other time periods are also presented in Table 4. The red crosses in the figures indicates the stationary sources. (b)

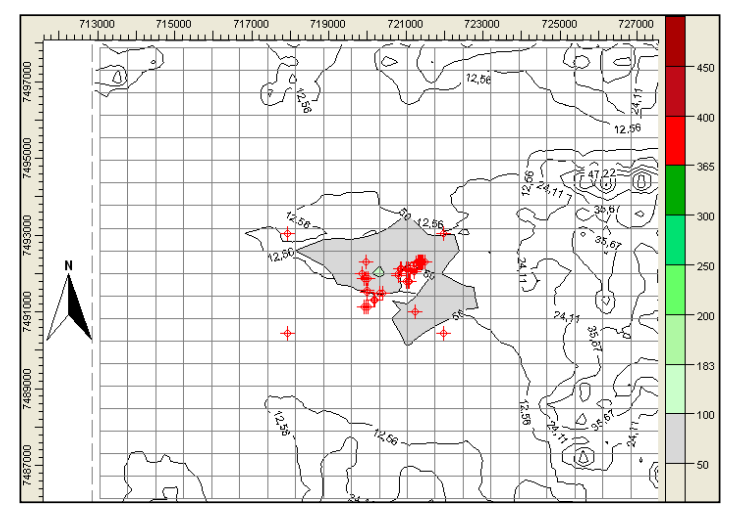

Figure 2. Average concentration $\left(\mu \mathrm{g} \mathrm{m}^{-3}\right)$ for the $1 \mathrm{~h}$ scenario for $\mathrm{NOx}(\mathrm{a})$ and $\mathrm{SO}_{2}$ (b) comprising $144 \mathrm{~km}^{2}$ around the main 42 chimneys (red crosses) of the petrochemical complex 
Using the data presented in Figure 2a, and analysing the results for hourly averages, it can be observed that the Brazilian primary standard for NOx $\left(320 \mathrm{mg} \mathrm{m}^{-3}\right)$ is exceeded when there is a red colour, while the Brazilian secondary standard for NOx $\left(190 \mu \mathrm{g} \mathrm{m}^{-3}\right)$ is exceeded when there is a green colour, which is a value close to the limit set by EU $\left(200 \mathrm{\mu g} \mathrm{m}^{-3}\right)$. It is possible to be more restrictive using the EPA limit $\left(100 \mathrm{\mu g} \mathrm{m}^{-3}\right)$, which was exceeded in almost the entire study area of $144 \mathrm{~km}^{2}$, except the white areas.

Figure $2 \mathrm{~b}$ shows the mean concentration of $\mathrm{SO}_{2}$ in $\mu \mathrm{g} \mathrm{m}^{-3}$ over a $24 \mathrm{~h}$ period for comparison with the values of the legislation for this period. With the information of Table 2 , it is possible to make a comparison with the legislated annual values and extrapolate for periods of less than $24 \mathrm{~h}$.

Figure $2 \mathrm{~b}$ shows a small area where the Brazilian secondary standard of $100 \mu \mathrm{g} \mathrm{m}^{-3}$ for $\mathrm{SO}_{2}$ was exceeded, which is a value close to the limit set by the EU $\left(125 \mu \mathrm{g} \mathrm{m} \mathrm{m}^{-3}\right)$. This area is represented by the lighter shade of green. However, the emissions did not reach even half of the Brazilian primary standard for $\mathrm{SO}_{2}\left(365 \mu \mathrm{g} \mathrm{m}^{-3}\right)$. Table 4 shows the mean maximum concentration in $\mu \mathrm{g} \mathrm{m}^{-3}$ for several periods also for $\mathrm{CO}$ and $\mathrm{PM}$.

Table 4. Maximum concentrations for $\mathrm{CO}, \mathrm{PM} 10, \mathrm{SO}_{2}$ and $\mathrm{NOx}$ for several modelled scenarios

\begin{tabular}{ccccc}
\hline Period & PM10 $\left(\mu \mathrm{g} \mathrm{m}^{-3}\right)$ & $\mathbf{S O}_{2}\left(\mu \mathrm{g} \mathrm{m}^{-3}\right)$ & NOx $\left(\mu \mathrm{g} \mathrm{m}^{-3}\right)$ & $\mathbf{C O}\left(\mu \mathrm{g} \mathrm{m}^{-3}\right)$ \\
\hline $1 \mathrm{~h}$ & 44 & 407 & 539 & 180 \\
$2 \mathrm{~h}$ & 24 & 352 & 306 & 103 \\
$3 \mathrm{~h}$ & 25 & 323 & 314 & 105 \\
$4 \mathrm{~h}$ & 21 & 316 & 265 & 90 \\
$6 \mathrm{~h}$ & 13 & 296 & 177 & 54 \\
$8 \mathrm{~h}$ & 11 & 216 & 149 & 46 \\
$12 \mathrm{~h}$ & 8 & 167 & 101 & 30 \\
$24 \mathrm{~h}$ & 5 & 117 & 66 & 18 \\
1 month & 2 & 30 & 25 & 7 \\
6 months & 1 & 23 & 21 & 5 \\
\hline
\end{tabular}

Dark gray represents a breach of the Brazilian primary standard, the standard medium gray the Brazilian secondary standard and the light gray the U.S. EPA.

Table 4 indicated that, for the longer average periods, the maximum value resulting in the study area for NOx was $21 \mu \mathrm{g}$ $\mathrm{m}^{-3}$, below the U.S. EPA limit of $100 \mu \mathrm{g} \mathrm{\textrm {m } ^ { - 3 }}$

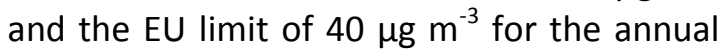
arithmetic mean for primary and secondary standards. The results for maximum NOx occurred in the centre of the complex in small sections. The values of NOx decrease when average time periods. This is to be expected because the results presented here showed the worst-case scenario. Table 4 presents a maximum observed value of $23 \mu \mathrm{g}$ $\mathrm{m}^{-3}$ for $\mathrm{SO}_{2}$ average over a period of six months. This value was below the U.S. EPA primary and secondary annual concentrations for this pollutant, 80 and 40 $\mu \mathrm{g} \mathrm{m}^{-3}$, respectively, and also for the EU limit of $125 \mathrm{\mu g} \mathrm{m}^{-3}$ for a $24 \mathrm{~h}$ period.

If primary and secondary limits were applied for periods of less than $24 \mathrm{~h}$ (not 
presented here), however the primary limit would be breached in average hourly limit while the secondary would be exceeded in all periods. The relatively low $\mathrm{SO}_{2}$ concentrations are the result of the petrochemical complex still being under construction and using desulphurised fuel oil. The use of another fuel oil would invalidate the simulations performed here.

The maximum values for $\mathrm{PM}_{10}$ in the 24hour period ( $5 \mathrm{\mu g} \mathrm{m}^{-3}$, see Table 4) were insignificant compared to the Brazilian maximum values of 240 and $150 \mathrm{\mu g} \mathrm{m}^{-3}$, the limits for primary and secondary total suspended particulates (TSP), and with 150 $\mu \mathrm{g} \mathrm{m}^{-3}$, the primary and secondary limit value for $\mathrm{PM}_{10}$. This statement was also true for all periods analysed. Moreover, comparing the values for the six month periods with the average annual limit set by Brazilian limits of $50 \mu \mathrm{g} \mathrm{m}^{-3}$ for $\mathrm{PM}_{10}$ (the same value set by the
EU) and $80 \mu \mathrm{g} \mathrm{m}^{-3}$ and $60 \mu \mathrm{g} \mathrm{m} \mathrm{m}^{-3}$ for PM, average annual primary and secondary thresholds for TSP were unlikely to be breached. A limitation of the simulation for $\mathrm{PM}_{10}$ is not considering the secondary formation of PM10 and this could be a significant source of this pollutant.

In Table 4, the highest CO value was 180 $\mu \mathrm{g} \mathrm{m}^{-3}$ for the maximum hourly average, which was orders of magnitude below those specified by Brazilian primary and secondary standards $\left(40,000 \mu \mathrm{g} \mathrm{m}^{-3}\right)$. Also in Table 4, the maximum value was $54 \mu \mathrm{g} \mathrm{m}^{-3}$ for $\mathrm{CO}$ in the 8 $\mathrm{h}$ period. This value is well below the standards specified by primary and secondary standards $\left(10,000 \mathrm{~g} \mathrm{~m}^{-3}\right)$, which is the same value set by the EU.

The simulation results for ozone for several scenarios using OZIPR/SAPRC are presented in Table 5.

Table 5. Ozone modelled results for several scenarios

\begin{tabular}{cccc}
\hline Scenario & Speciation & Emissions & Ozone (ppb) \\
\hline Base case & Downtown & RJMA $^{9}$ & 56.6 \\
1A & Refinery & RJMA - INEA & 50.0 \\
2A & Refinery & Petrochemical Complex (PC) & 62.0 \\
3A & Refinery & PC + (RJMA - INEA) & 47.8 \\
1B & Downtown & RJMA - INEA & 166 \\
2B & Downtown & PC & 199 \\
3B & Downtown & PC + RJMA - INEA & 155 \\
\hline
\end{tabular}

Note: In gray color, scenarios that provided ozone levels higher than Brazilian limits.

The "base case" was simulated to reproduce the results found by Corrêa et al. ${ }^{9}$ for the RJMA and to verify the consistency of the model. Worst results occurred for scenarios 1B, 2B and 3B, all of which exceeded ozone limits of 81 ppbv set by Brazilian law. ${ }^{1}$ In these scenarios, the initial concentration of pollutants and the speciation of VOC equal to the Rio de Janeiro downtown area were considered, scenarios where the speciation of VOC are typically biased to a more vehicular pollution. The difference in results between the two groups of scenarios, A and B, can be understood by the speciation adopted: the first group had more methane, which is less reactive for ozone chemistry, while the second speciation had a representative group of aromatics in its composition, which are more reactive. This justifies the high values (approximately 200 $\mathrm{ppb}$ ) found for this group of simulations. The subset of scenario B had values four times higher than the original case because of these differences in emissions. 
The cases that used the refinery speciation showed low ozone formation, which was justified by the fact that methane is present more in the hydrocarbon monitoring. The refinery, therefore, can be a separate case when attempting to characterise the petrochemical complex, since the methane originates from the processes of compression and processing natural gas, which are not present in the petrochemical complex. Furthermore, emission inventories for the RJMA and for the petrochemical complex, when viewed separately, have values slightly higher than when these inventories are combined. The sensitivity charts (Figure $3 a$ and $3 b$ ) and isopleth graphs (Figure $4 a$ and $4 b$ ) support this explanation. (a)

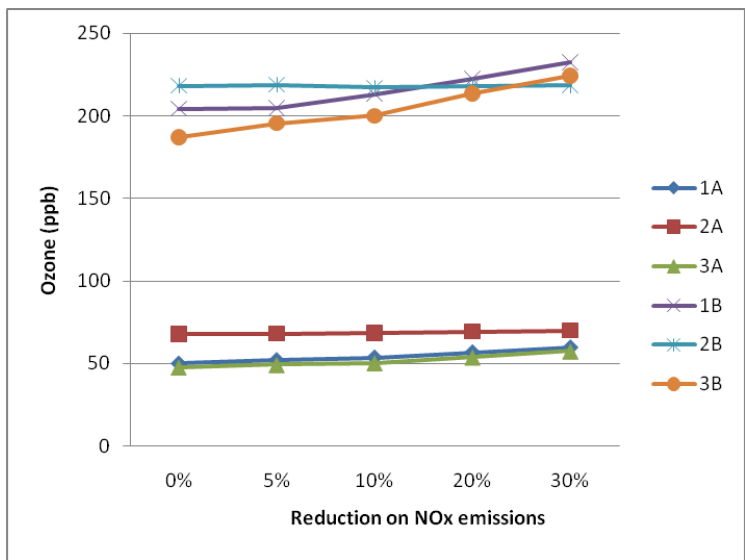

(b)

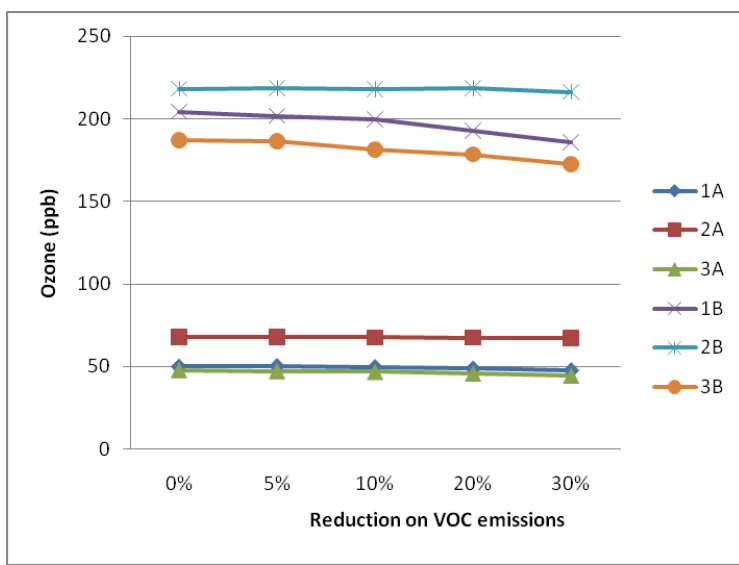

Figure 3. Sensitivity chart of ozone levels as a function of different NOx (a) and VOCs (b) emissions

When VOC/NOx emissions ratios are greater than 5.5 (7.5 in the present case), the atmosphere is considered to be controlled by VOC, and to change the rate of ozone formation, one must change the NOx emissions. ${ }^{6}$ Therefore, one conclude that a decrease in NOx emissions lead to higher ozone formation. Conversely, a decrease in the emissions of VOC promoted a reduction in ozone formation.

In the chart of isopleths of scenario $2 \mathrm{~A}$ (Figure $4 \mathrm{a}$, with refinery VOC speciation), the initial concentration of pollutants is presented with a solid black circle. An increase in NOx emissions or a decrease in VOC emissions from this position would lead to a lower ozone formation. This would explain why, when inventories are added, there is a decrease in ozone formation (i.e., as emissions from the petrochemical complex were higher in NOx, rises in the isopleth curves occurred with less ozone formation).

In isopleths of scenario 2B (Figure 4b), with the solid black circle representing the initial concentration of pollutants, an increase or decrease of NOx led to the same result: reduction in ozone formation. However, this decline requires significant emission changes to be effective in ozone formation. In contrast, a brief decrease in VOC emissions would be far more effective in reducing ozone formation.

Hence, it appears that the more effective action to reduce ozone, independent of scenarios, would be a reduction in VOC emissions. This result diverges from the observed relationships for VOC/NOx presented in similar cases. 
(a)

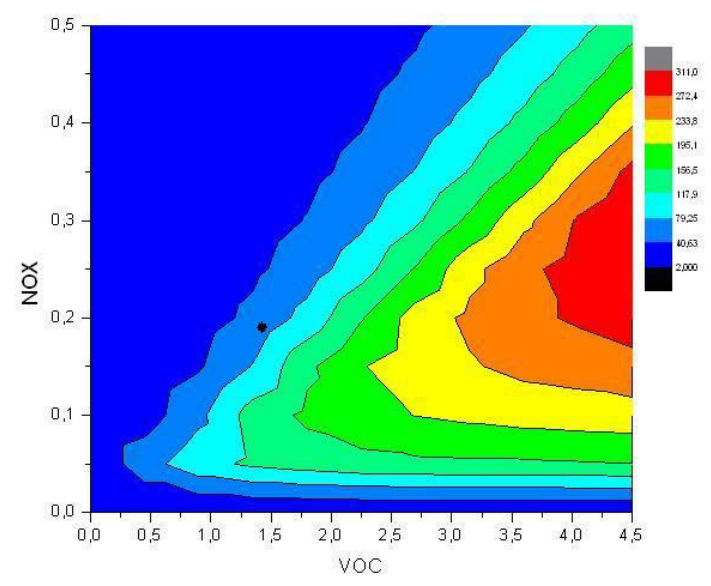

(b)

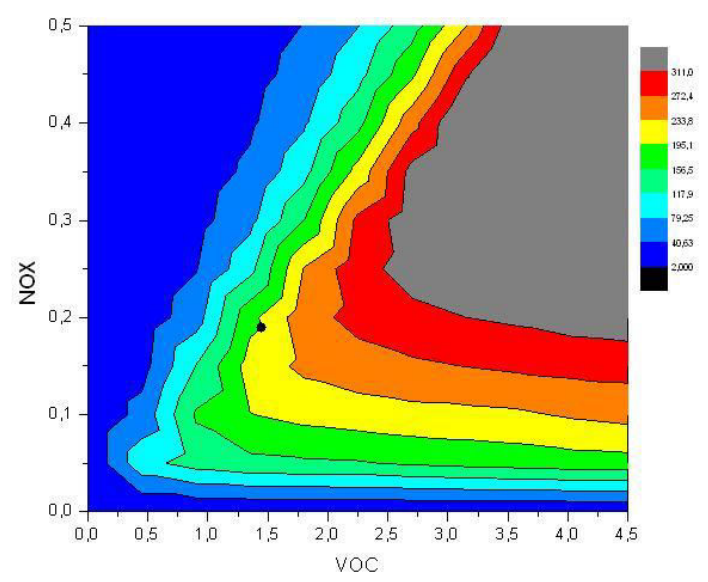

Figure 4. Ozone isopleth (in ppb) for refinery VOCs speciation (scenario 2A) (a) and ozone isopleth from Corrêa et al. ${ }^{9}$ (b) for VOCs speciation (scenario 2B)

According to the results presented in Table 6 VOC incremental reactivity for scenario $2 \mathrm{~A}$ indicated the main molecules for monitoring and control. These results show that the methodology and results presented here can be used by environmental agencies to refine management policies.

Table 6. Incremental reactivity (IR) scale for major VOC (scenario 2A)

\begin{tabular}{cc}
\hline VOC & IR \\
\hline methane & 0.844 \\
isobutene & 0.821 \\
2,3-dimethyl 1-butene & 0.821 \\
1,3-butadiene & 0.821 \\
cyclohexene & 0.821 \\
2-methyl 2-pentene & 0.821 \\
formaldehyde & 0.807 \\
acetaldehyde & 0.806 \\
acetone & 0.757 \\
benzaldehyde & 0.753 \\
methyl cyclohexane & 0.752 \\
p-xylene & 0.750 \\
naphthalene & 0.750 \\
m-xylene & 0.750 \\
1,2,3-trimethyl benzene & 0.750 \\
1,3,5-trimethyl benzene & 0.750 \\
styrene & 0.750 \\
o-xylene & 0.748 \\
propene & 0.747 \\
1-butene & 0.747 \\
1-pentene & 0.747 \\
1,3-dimethyl & \\
cyclopentane & 0.741 \\
propyl benzene & 0.740 \\
cumene & 0.740
\end{tabular}




\begin{tabular}{cc}
\hline VOC & IR \\
\hline ethyl benzene & 0.740 \\
ethane & 0.738 \\
n-butane & 0.738 \\
2-methyl butane & 0.738 \\
n-hexane & 0.738 \\
2,3-dimethyl butane & 0.738 \\
t-butanol & 0.738 \\
ethanol & 0.738 \\
benzene & 0.736 \\
chloro benzene & 0.707 \\
toluene & 0.668 \\
1,2,4-trimethyl benzene & 0.356 \\
\hline
\end{tabular}

Applying the reactivity scale ${ }^{11}$ on the 10 main VOCs of Table 6 , it was possible to find some similarities: 2,3-dimethyl-1-butene, cis3-hexene, 2-methyl-2-pentene, 2-methyl-1pentene and isobutene were all indicated as important VOC in both reports. The same results were found for the São Paulo Metropolitan Area. ${ }^{6}$ Surprisingly, despite low methane reactivity, it appeared to be the most important VOC. This could be explained because the methane quantity was almost double the total of all other VOC, diluting the fraction of the other VOC species present. A decrease in methane quantity prompted a relative increase in the other VOC species and thus increased the capacity to form ozone. The presence of methane could explain the fact that, despite the observation that atmospheric chemistry is controlled by the VOC in the region (for VOC/NOx greater than 5.5), the formation of ozone is still sensitive to NOx. In fact, by removing methane, the ratio VOC/NOx was lower than 5.5. In this case, atmospheric chemistry was controlled by NOx, so the formation of ozone was no longer sensitive to the presence of VOC.

\section{Conclusions}

The lack of accurate information on industries implies that, despite simplifications, the Gaussian models are a good approximation to real values. Therefore, they are conservative and useful for regulatory cases.

According to the evaluations done in this work, NOx is the most critical pollutant and its concentration was found to exceed the primary and secondary Brazilian national standards. As such, it is the parameter that should be most closely monitored by air quality monitoring stations.

Sulphur dioxide is dependent on the fuel used, so if a fuel with higher sulphur content from that adopted by this work is used the simulations must be repeated.

As regards carbon monoxide and particulate matter, the emissions were found to be dependent on the way an industrial unit is operated. Therefore, the petrochemical complex has to train its operation and maintenance teams so that the values of these emissions are kept within the limits of the theoretical data used for the implementation of the simulations performed here.

Using refinery $\mathrm{VOC}$ speciation, the highest calculated ozone values were found to be near the legislative limits, but not higher. In cases where the VOC speciation of Corrêa et al. ${ }^{9}$ was used, values found for ozone in mainly downtown areas were near the Brazilian national standard. In the modelling presented here, the RJMA was considered to be essentially industrial, while the data from the downtown area was considered to be 
primarily affected by vehicular pollution. Using these two limit cases, the numerical results for ozone formation were quite different, but the same indication for the solution to ozone formation was obtained, namely a control of the VOCs emissions to minimise ozone levels.

\section{References}

${ }^{1}$ CONAMA. Resolution no. 03, June 28, 1990. [Link]

${ }^{2}$ Lora, E. E. S.; Prevention and Pollution Control in Energetic, Industrial and Transport Sectors, Editora Interciência: Rio de Janeiro, ISBN 978-85-719-3066-7, 2002.

${ }^{3}$ Cheremisinof, N. P.; Handbook of Air Pollution Prevention and Control, Elsevier Science, Butterworth-Heinemann, ISBN 9780-7506-7499-7, 2002.

${ }^{4}$ BEN - National Energy Balance, 2008. [Link]

${ }^{5}$ Carter, W. P. L. A detailed mechanism for the gas-phases atmospheric reactions of organic compounds. Atmospheric Environment 1990, 24, 481. [CrossRef]

${ }^{6}$ Orlando, J. P.; Alvim, D. S.; Yamazaki, A.; Corrêa, S. M.; Gatti, L. V. Ozone precursors for the São Paulo Metropolitan Area. Science of the Total Environment 2010, 408, 1612. [CrossRef]

${ }^{7}$ Guimarães, C. S.; Arbilla, G.; Corrêa, S. M.; Gatti, L. V. Impact of aircraft traffic emissions on ozone formation at the Rio de Janeiro urban area. Periódico Tchê Química 2007, 4, 21. [Link]

${ }^{8}$ Campos, I. C. B.; Pimentel, A. S.; Corrêa, S. M.; Arbilla, G. Simulation of Air Pollution from Mobile Source Emissions in Rio de Janeiro City. Journal of the Brazilian Chemical Society 1999, 10, 203. [CrossRef]

${ }^{9}$ Corrêa, S. M.; Silva, C. V.; Sodré, E. D.; Teixeira, J. R. Volatile Organic Compound Emissions from a Landfill, Plume Dispersion and the Tropospheric Ozone Modeling. Journal of the Brazilian Chemical Society 2012, 23, 496. [CrossRef]
${ }^{10}$ Corrêa, S. M.; Arbilla, G.; Martins, E. S.; Quitério, S. L.; Souza, G. C.; Gatti, L. V. Fiveyears of Formaldehyde and Acetaldehyde Monitoring in the Rio de Janeiro Downtown Area - Brazil. Atmospheric Environment 2010, 44, 2302. [CrossRef]

${ }^{11}$ Finlayson-Pitts, B. J; Pitts, J. N. Jr. Chemistry of the Upper and Lower Atmosphere: Theory, Experiments and Applications, Academic Press, San Diego, ISBN 978-0-12-257060-5, 2000

12 Holmes, N. S.; Morawska, L. A review of dispersion modeling and its application to the dispersion of particles: An overview of different dispersion models available. Atmospheric Environment 2006, 40, 5902. [CrossRef]

${ }^{13}$ Souto González, J. A.; Bello Bugallo, P. M.; Casares Long, J. J. Evaluation of air pollution modeling tools as environmental engineering courseware. Water Science and Technology 2004, 49, 57. [Link]

${ }^{14}$ Mehdizadeh, F.; Rifai, H. S. Modeling point source plumes at high altitudes using a modified Gaussian model. Atmospheric Environment 2004, 38, 821. [CrossRef]

${ }^{15}$ Zhou, Y.; Levy, J. I.; Hammitt, J. K.; Evans, J. S. Estimating population exposure to power plant emissions using CALPUFF: A case study in Beijing, China, Atmospheric Environment 2003, 37, 815. [CrossRef]

${ }^{16}$ Corrêa, S. M.; Arbilla, G.; Marques, M. R. C.; Oliveira, K. M. P. G. The impact of BTEX emissions from gas stations into the atmosphere. Atmospheric Pollution Research 2012, 3, 163. [CrossRef]

${ }^{17}$ EIA (Environmental Impact Report). Petrochemical Complex of Rio de Janeiro, 2007, [Link]

${ }^{18}$ U.S. EPA. AERMOD: Description of Model Formulation. EPA-454/R-03-004, 2004. [Link]

${ }^{19}$ Gery, M. W.; Crouse, R. R. User's Guide for Executing OZIPR, U.S. Environmental Protection Agency, Research Triangle Park, N. C., EPA-9D2196NASA, 1990. [Link]

${ }^{20}$ Tonnesen, G. S. User's Guide for Executing OZIPR Version 2.0, U.S.EPA, 2000. 
${ }^{21}$ Martins, E. M.; Nunes, A. C. L.; Corrêa, S. M. Understanding Ozone Concentrations During Weekdays and Weekends in the Urban Area of the City of Rio de Janeiro. Journal of the Brazilian Chemical Society 2015, 26, 1967. [CrossRef]

${ }^{22}$ U. S. EPA. Method TO-14A - Determination of Volatile Organic Compounds (VOCs) in Ambient Air Using Specially Prepared Canisters with Subsequent Analysis by Gas Chromatography, 1999a. [Link]

${ }^{23}$ U. S. EPA. Method TO-15A - Determination of Volatile Organic Compounds (VOCs) in Air Collected in Specially-Prepared Canisters And Analyzed by Gas Chromatography/ Mass Spectrometry, 1999b. [Link]

${ }^{24}$ U. S. EPA. Method TO-11A - Determination of Formaldehyde in Ambient Air Using Adsorbent Cartridge Followed by High
Performance Liquid Chromatography (HPLC), 1999c. [Link]

${ }^{25}$ Corrêa, S. M.; Arbilla, G.; Martins, E. M. Formaldehyde and acetaldehyde in a high traffic street of Rio de Janeiro, Brazil. Atmospheric Environment 2003, 37, 23. [CrossRef]

${ }^{26}$ Corrêa, S. M.; Arbilla, G. Formaldehyde and acetaldehyde associated with the use of natural gas as a fuel for light vehicles. Atmospheric Environment 2005, 39, 4513. [CrossRef]

${ }^{27}$ Corrêa, S. M.; Arbilla, G. Carbonyl emissions in diesel and biodiesel exhaust. Atmospheric Environment 2008, 42, 769. [CrossRef]

${ }^{28}$ INEA. Annual Air Quality Report for Rio de Janeiro State for the Years of 2010 and 2011, Rio de Janeiro, Brazil, 2012. [Link] 